\title{
The River Turtles of the Amazon
}

\section{By J. J. C. Mallinson}

IN Brazil until quite recently the river turtle Podocnemis expansa, locally known as the tartaruga, was a staple item of diet for people in the riverine towns; today it is becoming more and more difficult to find in populated regions, and is regarded as a luxury item. Each morning while I was at Guajara-Mirim, on the BoliviaBrazil border, I watched the landing of these turtles from heavily laden canoes; in the market adult specimens were fetching the equivalent of 50 shillings each. On the local Mamoré-Madeira railway I saw a goods van loaded with about seventy turtles piled on top of one another. When I travelled on this railway with the turtles to Porto Velho, some two days journey from Guajara-Mirim, about a quarter of them were dead on arrival. As the trains run twice a week, and I was told that it always carried a good load of turtles between June and December, when they are easy to come by because the rivers are low, this meant that some 3,000-4,000 turtles were transported in those six months to Porto Velho; there they find a ready market because, due to overhunting, they are seldom to be found. Now a road is being built between the two towns, which will reduce the journey to one day, and no doubt increase the drain on the turtles.

In Manaus I talked to Dr Paul Anthony, who is connected with the Instituto Nacional de Pesquisas da Amazonia. Each year permits are issued and a fee paid to the local authorities, granting to permit holders control over a certain river beach, stipulating the numbers of turtles that may be marketed, and forbidding the collection of eggs. Unfortunately, this written protection gets no further than the official's office. The turtles lay from September to November, and the hunters regard this period as their chief harvesting time. The turtles are easily upturned on the beaches, and both females and eggs are collected. They may lay up to 140 eggs. From December to May the turtle stands a better chance of survival in the swollen waters of the rivers, but they are still caught if located.

The result is that this small economic asset, derived from the yearly issue of licences to the commercial turtle hunters, will soon bu lost to the treasury. If the authorities would enforce a close season during the egg laying, by banning turtle sales in public markets and the transport of turtles on the railway, it would be to the benefit of government, people and turtles. Not only would it guarantee the continuance of the licence revenue, but also give the short-sighted commercial turtle-hunters a permanent livelihood, safeguard a food supply and check the over-hunting. If the present rate of killing continues the river turtles' only sanctuary will be the remote and unpopulated jungle regions. 